\title{
Polyphyly and two emerging lineages in the rust genera Puccinia and Uromyces
}

\author{
Wolfgang Maier $^{\mathrm{a}}$, Brenda D. Wingfield ${ }^{\mathrm{a}}$, Mechthilde Mennicken ${ }^{\mathrm{b}}$ and \\ Michael J. Wingfield ${ }^{\mathrm{a}}$
}

${ }^{a}$ University of Pretoria, Department of Genetics, Forestry and Agricultural Biotechnology Institute (FABI), Pretoria 0002, South Africa

${ }^{\mathrm{b}}$ Dolziger Str. 48, 10247 Berlin, Germany

\begin{abstract}
The phylogenetic validity of Puccinia and Uromyces, Pucciniaceae, and closely related genera was evaluated using nucLSU rDNA sequences. Using a wide range of rust species with different life cycles and with different host specificities, Puccinia and Uromyces were shown to be highly polyphyletic and to also include representatives of the genera Aecidium, Cumminsiella, Dietelia, Endophyllum, Miyagia, and Uredo. Furthermore, the structure of the phylogenetic data did not reflect previous sub-generic delimitations based on teliospore pedicel structure, but rather suggests that at least two major lineages have evolved within Puccinia/Uromyces: Rusts with telial states on Poaceae were exclusively found in one of these groupings and those with telial states on Cyperaceae resided in the other lineage. This might suggest that the two lineages evolved in close association with these host groups in different biomes.
\end{abstract}

\section{Article Outline}

Introduction

Materials and methods

Sample collection and identification

DNA-isolation, PCR and DNA-sequencing 
DNA-sequencing and phylogenetic analyses

Results

Data structure

Phylogenetic trees

Species circumscription as reflected by the phylogenetic data

Discussion

Sub-generic classification and the host relationships of phylogenetic groupings

Geographical patterns

Addendum

Acknowledgements

Appendix. Supplementary material

References

\section{Introduction}

Puccinia and Uromyces are by far the two largest genera of rust fungi (Pucciniales), currently including some 4000 and 600 described species, respectively (Cummins \& Hiratsuka 2003). These genera have a world-wide distribution and they constitute the vast majority of the rust flora on all six continents (compare McAlpine, 1906, Tranzschel, 1939, Doidge, 1950, Gäumann, 1959 and Hennen et al., 2005).

Puccinia and Uromyces cannot be distinguished by the morphology of their spermogonia, aecia or uredinia or the respective spore types produced within these structures. Thus, the generic definitions were simply based on the number of the teliospore cells, which are one-celled in Uromyces and two-celled in Puccinia. This simplistic scheme is complicated by the fact, that there are species having both one- and two-celled teliospores and sometimes three- and four-celled spores. In these cases, the species have typically been relegated to Puccinia, and the one-celled teliospores have been referred to as mesospores (Gäumann 1926). For these reasons and because of the homogeneity in the morphology of the sori and spores other than teliospores, it has repeatedly been noted that Puccinia and Uromyces are not natural or monophyletic genera (Tulasne, 1854, Sydow and Sydow, 1904, Sydow and Sydow, 1910, Arthur, 1934, Guyot, 1938 and Leppik, 1959). 
Arthur (1906) made the first attempt at splitting the genera Puccinia and Uromyces into smaller and more manageable taxa based solely on life-cycle characteristics. This approach was legitimately criticised by Sydow (1921) and Dietel, 1922a and Dietel, 1922b, because Dietel (1899) had previously demonstrated the phylogenetic connection between a macrocyclic ( $P$. coronata) and a microcyclic rust (P. mesneriana) based on teliospore morphology. Details of this concept were greatly elaborated by Tranzschel (1904), and Tranzschel's law stating that microcyclic autoecious rusts can be linked phylogenetically to macrocyclic heteroecious rusts and their telia will occur on the former aecial host thus emerged. Because of Tranzschel's law, it became evident that a life-cycle based generic concept must lead to placement of very closely related species into different genera. Arthur (1934) consequently abandoned his life-cycle concept of genera and retained Puccinia and Uromyces based on their classical circumscription. Phylogenetically, however, he treated them as if they were one big genus. Below the genus level the robustness of the teliospore pedicel has been used to group species of both Puccinia and Uromyces (Fischer, 1904, Klebahn, 1914 and Gäumann, 1959). Arthur (1934) defined the subgenera Bullaria with fragile pedicels and consequently dehiscent teliospores and Eu-Puccinia with firm pedicels and consequently persistent teliospores, and also included Uromyces in this subgeneric definition. Besides the giant genera Puccinia and Uromyces, there are various closely related satellite genera that have been described based on peculiarities of their life-cycles or teliospore morphology. Thus, Endophyllum (Léveillé 1826) is defined by a special lifecycle or ontogeny, in which the Puccinia-type aeciospores germinate to produce basidia. The same holds true for Dietelia (Hennings 1897), which forms part of the presumably polyphyletic Pucciniosiraceae that includes only endocyclic representatives. Miyagia (Miyabe 1913) has been treated as a discrete genus because of the presence of paraphyses around the telia. Cumminsiella was split from Uropyxis, where it had originally been accommodated due to similar teliospore morphology, because of its Puccinia-like spermogonial and uredinial morphology (Arthur 1933).

Contemporary evidence based on molecular phylogenetic studies using different gene regions has accumulated in support of early evidence contesting the monophyly of Puccinia and Uromyces. Thus, in an ITS-based study, it was found that Puccinia hordei, 
which produces both one- and two-celled teliospores, is more closely related to Uromyces scillarum than to other Puccinia species "and may be closely related to Uromyces leaf rusts on Hordeum" (Zambino \& Szabo 1993). With the help of nucLSU rDNA data, it was shown that both Puccinia and Uromyces are polyphyletic, but also encompass Cumminsiella and Endophyllum (Maier et al. 2003). Likewise, using nucSSU rDNA data, it has been demonstrated that Miyagia and Dietelia belong to the monophyletic PucciniaUromyces cluster (Wingfield et al. 2004). The fact that Endophyllum is embedded in Puccinia and that Puccinia and Uromyces are polyphlyetic could also be deduced from another phylogenetic study using ITS sequences (Wood \& Crous 2005). However, none of these DNA sequence-based studies have adequately considered the broader implications of their results. This is because the questions addressed in these studies were specific to particular groups of species and none of the studies included a large number of representatives of Uromyces and Puccinia.

In this study, we consider the phylogenetic relationships between the genera Puccinia, Uromyces, Cumminsiella, Miyagia, Dietelia and Endophyllum in considerably greater detail than has previously been attempted. The primary focus of interest is to find characters that correlate with natural groupings in the Puccinia/Uromyces complex, which eventually could help in promote a better understanding of this diverse and important group of rust fungi. Therefore, Puccinia and Uromyces species infecting a variety of plant families and displaying many different life cycle strategies were sampled.

\section{Materials and methods}

\section{Sample collection and identification}

The European samples included in this study were mainly collected by W.M., and then identified using light microscopy. Most of the southern African specimens were collected and identified by M.M. (Mennicken and Oberwinkler, 2004, Mennicken et al., 2005a, Mennicken et al., 2005b and Mennicken et al., 2005c). Specimens that were used in this study, with additional information on host species, life-cycle, geographic origin and GenBank accession numbers can be found in Table 1 . 


\section{Table 1.}

Species and specimens used in the present study

\begin{tabular}{|c|c|c|c|c|c|c|}
\hline Rust species & Host species & I-host & III-host & $\begin{array}{l}\text { GenBank } \\
\text { accession no. }\end{array}$ & Voucher & $\begin{array}{l}\text { Geographical } \\
\text { origin }\end{array}$ \\
\hline Aecidium sp. & Elaeagnus parvifolia & Elaeagnaceae & $?$ & DQ917721 & WM 3523 & As \\
\hline Chrysomyxa empetri & Empetrum nigrum & (Pinaceae) & (Ericaceae) & DQ917750 & $\begin{array}{l}\text { CFB } \\
22242\end{array}$ & NA \\
\hline $\begin{array}{l}\text { Cumminsiella } \\
\text { mirabilissima }\end{array}$ & Mahonia aquifolium & Berberidaceae & Berberidaceae & (AF426206) & $\begin{array}{l}\text { TUB } \\
014955\end{array}$ & $\mathrm{CE}$ \\
\hline $\begin{array}{l}\text { Dietelia } \\
\text { mesoamericana }\end{array}$ & Mikania micrantha & Asteraceae & - & DQ917691 & $\begin{array}{l}\text { IMI } \\
393070\end{array}$ & CA \\
\hline $\begin{array}{l}\text { Endophyllum } \\
\text { euphorbiae-sylvaticae }\end{array}$ & $\begin{array}{l}\text { Euphorbia } \\
\text { amygdaloides }\end{array}$ & Euphorbiaceae & - & (AF426200) & $\begin{array}{l}\text { HeRB C- } \\
82 \text { in ZT }\end{array}$ & $\mathrm{CE}$ \\
\hline $\begin{array}{l}\text { Endophyllum } \\
\text { sempervivi }\end{array}$ & Sempervivum tectorum & Crassulaceae & - & DQ917747 & $\begin{array}{l}\text { TUB } \\
014957\end{array}$ & $\mathrm{CE}$ \\
\hline $\begin{array}{l}\text { Gymnosporangium } \\
\text { sabinae }\end{array}$ & Pyrus communis & (Rosaceae) & (Cupressaceae) & (AF426209) & $\begin{array}{l}\text { TUB } \\
014958\end{array}$ & $\mathrm{CE}$ \\
\hline $\begin{array}{l}\text { Miyagia } \\
\text { pseudosphaeria }\end{array}$ & Sonchus cf. oleraceus & - & Asteraceae & DQ917704 & RSA 173 & SAf \\
\hline $\begin{array}{l}\text { Miyagia } \\
\text { pseudosphaeria }\end{array}$ & Sonchus cf. oleraceus & - & Asteraceae & DQ917705 & RSA 125 & SAf \\
\hline $\begin{array}{l}\text { Puccinia actaeae- } \\
\text { agropyri }\end{array}$ & Actaea spicata & Ranunculaceae & Poaceae & DQ917746 & $\begin{array}{l}\text { TUB } \\
014959\end{array}$ & $\mathrm{CE}$ \\
\hline
\end{tabular}




\begin{tabular}{|c|c|c|c|c|c|c|}
\hline Rust species & Host species & I-host & III-host & $\begin{array}{l}\text { GenBank } \\
\text { accession no. }\end{array}$ & Voucher & $\begin{array}{l}\text { Geographical } \\
\text { origin }\end{array}$ \\
\hline Puccinia aegopodii & $\begin{array}{l}\text { Aegopodium } \\
\text { podagraria }\end{array}$ & - & Apiaceae & DQ917698 & $\begin{array}{l}\text { TUB } \\
014960\end{array}$ & $\mathrm{CE}$ \\
\hline Puccinia arenariae & Dianthus barbatus & - & Caryophyllaceae & DQ917731 & $\begin{array}{l}\text { TUB } \\
014961\end{array}$ & $\mathrm{CE}$ \\
\hline $\begin{array}{l}\text { Puccinia arenariicola } \\
\text { var. caricis-montanae }\end{array}$ & Carex alba & Asteraceae & Cyperaceae & DQ917686 & FO 3195 & $\mathrm{CE}$ \\
\hline Puccinia aridariae & $\begin{array}{l}\text { Mesembryanthemum } \\
\text { guerichianum }\end{array}$ & $?$ & Aizoaceae & DQ917724 & RSA 153 & SAf \\
\hline Puccinia aridariae & Aridaria noctiflora & $?$ & Aizoaceae & DQ917725 & RSA 155 & SAf \\
\hline Puccinia asarina & Asarum europaeum & - & Aristolochiaceae & DQ917732 & $\begin{array}{l}\text { TUB } \\
014962\end{array}$ & $\mathrm{CE}$ \\
\hline Puccinia bardanae & Arctium lappa & - & Asteraceae & DQ917703 & $\begin{array}{l}\text { TUB } \\
014963\end{array}$ & $\mathrm{CE}$ \\
\hline Puccinia bistortae & Polygonum bistorta & Apiaceae & Polygonaceae & DQ917697 & $\begin{array}{l}\text { TUB } \\
014964\end{array}$ & $\mathrm{CE}$ \\
\hline Puccinia calthicola & Caltha palustris & Ranunculaceae & Ranunculaceae & DQ917701 & $\begin{array}{l}\text { TUB } \\
014965\end{array}$ & $\mathrm{CE}$ \\
\hline $\begin{array}{l}\text { Puccina caricinia var. } \\
\text { ribesii-diversicoloris }\end{array}$ & Carex flacca & Grossulariaceae & Cyperaceae & DQ917695 & $\begin{array}{l}\text { TUB } \\
014966\end{array}$ & $\mathrm{CE}$ \\
\hline $\begin{array}{l}\text { Puccinia caricina var. } \\
\text { ribesii-ferrugineae }\end{array}$ & Carex ferruginea & Grossulariaceae & Cyperaceae & DQ917694 & $\begin{array}{l}\text { TUB } \\
014967\end{array}$ & $\mathrm{CE}$ \\
\hline Puccinia caricina var. & Carex pendula & Grossulariaceae & Cyperaceae & DQ917693 & TUB & $\mathrm{CE}$ \\
\hline
\end{tabular}




\begin{tabular}{|c|c|c|c|c|c|c|}
\hline Rust species & Host species & I-host & III-host & $\begin{array}{l}\text { GenBank } \\
\text { accession no. }\end{array}$ & Voucher & $\begin{array}{l}\text { Geographical } \\
\text { origin }\end{array}$ \\
\hline ribesii-pendulae & & & & & 014968 & \\
\hline Puccinia cf. helianthi & Helianthus annuus & Asteraceae & Asteraceae & DQ917711 & WM 3524 & SAf \\
\hline Puccinia circaeae & Circaea lutetiana & - & Onagraceae & DQ917716 & $\begin{array}{l}\text { TUB } \\
014969\end{array}$ & $\mathrm{CE}$ \\
\hline Puccinia coronata & Rhamnus cathartica & Rhamnaceae & Poaceae & DQ917741 & $\begin{array}{l}\text { TUB } \\
014970\end{array}$ & $\mathrm{CE}$ \\
\hline $\begin{array}{l}\text { Puccinia dioicae var. } \\
\text { dioicae }\end{array}$ & Carex davalliana & Asteraceae & Cyperaceae & DQ917687 & $\begin{array}{l}\text { TUB } \\
014971\end{array}$ & $\mathrm{CE}$ \\
\hline $\begin{array}{l}\text { Puccinia extensicola } \\
\text { var. linosyridi-caricis }\end{array}$ & Carex humilis & Asteraceae & Cyperaceae & DQ917685 & $\begin{array}{l}\text { TUB } \\
014972\end{array}$ & $\mathrm{CE}$ \\
\hline Puccinia firma & Carex firma & Asteraceae & Cyperaceae & DQ917696 & $\begin{array}{l}\text { TUB } \\
014973\end{array}$ & $\mathrm{CE}$ \\
\hline Puccinia galeniae & Galenia crystallina & $?$ & Aizoaceae & DQ917729 & RSA 162 & SAf \\
\hline Puccinia galeniae & Aizoon canariense & $?$ & Aizoaceae & DQ917730 & RSA 148 & SAf \\
\hline Puccinia gigantea & $\begin{array}{l}\text { Epilobium } \\
\text { angustifolium }\end{array}$ & - & Onagraceae & (AF426198) & $\begin{array}{l}\text { TUB } \\
014974\end{array}$ & $\mathrm{CE}$ \\
\hline $\begin{array}{l}\text { Puccinia graminis } \mathrm{f} \text {. } \\
\text { sp. tritici }\end{array}$ & Triticum aestivum & Berberidaceae & Poaceae & (L08728) & & NA \\
\hline Puccinia hieracii & Hieracium murorum & - & Asteraceae & DQ917688 & $\begin{array}{l}\text { TUB } \\
014975\end{array}$ & $\mathrm{CE}$ \\
\hline Puccinia impatientis & Adoxa moschatellina & Adoxaceae & Balsaminaceae & DQ917700 & TUB & $\mathrm{CE}$ \\
\hline
\end{tabular}




\begin{tabular}{|c|c|c|c|c|c|c|}
\hline Rust species & Host species & I-host & III-host & $\begin{array}{l}\text { GenBank } \\
\text { accession no. }\end{array}$ & Voucher & $\begin{array}{l}\text { Geographical } \\
\text { origin }\end{array}$ \\
\hline & & & & & 014976 & \\
\hline $\begin{array}{l}\text { Puccinia } \\
\text { knersvlaktensis }\end{array}$ & $\begin{array}{l}\text { Mesembryanthemum } \\
\text { nodiflorum }\end{array}$ & - & Aizoaceae & DQ917727 & RSA 33 & SAf \\
\hline $\begin{array}{l}\text { Puccinia } \\
\text { knersvlaktensis }\end{array}$ & $\begin{array}{l}\text { Mesembryanthemum } \\
\text { nodiflorum }\end{array}$ & - & Aizoaceae & DQ917726 & RSA 176 & SAf \\
\hline Puccinia lagenophorae & Bellis perennis & Asteraceae & Asteraceae & DQ917692 & $\begin{array}{l}\text { TUB } \\
014977\end{array}$ & $\mathrm{CE}$ \\
\hline $\begin{array}{l}\text { Puccinia luzulae- } \\
\text { maximae }\end{array}$ & Luzula sylvatica & $?$ & Juncaceae & DQ917689 & $\begin{array}{l}\text { TUB } \\
014978\end{array}$ & $\mathrm{CE}$ \\
\hline Puccinia malvacearum & Alcea rosea & Malvaceae & Malvaceae & (AF426208) & $\begin{array}{l}\text { TUB } \\
014979\end{array}$ & $\mathrm{CE}$ \\
\hline Puccinia menthae & Mentha $\times$ piperita & Lamiaceae & Lamiaceae & DQ917712 & $\begin{array}{l}\text { TUB } \\
014980\end{array}$ & $\mathrm{CE}$ \\
\hline $\begin{array}{l}\text { Puccinia } \\
\text { mesembryanthemi }\end{array}$ & $\begin{array}{l}\text { Psilocaulon } \\
\text { leptarthron }\end{array}$ & Aizoaceae & Aizoaceae & DQ917728 & RSA 166 & SAf \\
\hline Puccinia otzeniani & $\begin{array}{l}\text { Lampranthus } \\
\text { otzenianus }\end{array}$ & Aizoaceae & Aizoaceae & DQ917742 & RSA 164 & SAf \\
\hline Puccinia oxyriae & Oxyria digyna & $?$ & Polygonaceae & DQ917735 & $\begin{array}{l}\text { TUB } \\
014981\end{array}$ & NE \\
\hline Puccinia poarum & Tussilago farfara & Asteraceae & Poaceae & DQ917748 & $\begin{array}{l}\text { TUB } \\
014982\end{array}$ & $\mathrm{CE}$ \\
\hline Puccinia polygoni- & Persicaria amphibia & Geraniaceae & Polygonaceae & DQ917702 & FO 47837 & $\mathrm{CE}$ \\
\hline
\end{tabular}




\begin{tabular}{|c|c|c|c|c|c|c|}
\hline Rust species & Host species & I-host & III-host & $\begin{array}{l}\text { GenBank } \\
\text { accession no. }\end{array}$ & Voucher & $\begin{array}{l}\text { Geographical } \\
\text { origin }\end{array}$ \\
\hline \multicolumn{7}{|l|}{ amphibii } \\
\hline Puccinia punctiformis & Cirsium arvense & Asteraceae & Asteraceae & DQ917706 & $\begin{array}{l}\text { TUB } \\
014983\end{array}$ & $\mathrm{CE}$ \\
\hline Puccinia saxifragae & Saxifraga hieracifolia & - & Saxifragaceae & DQ917734 & $\begin{array}{l}\text { TUB } \\
014984\end{array}$ & NE \\
\hline Puccinia senecionis & Senecio cacaliaster & - & Asteraceae & DQ917699 & $\begin{array}{l}\text { TUB } \\
014985\end{array}$ & $\mathrm{CE}$ \\
\hline $\begin{array}{l}\text { Puccinia senecionis- } \\
\text { acutiformis }\end{array}$ & Senecio ovatus & Asteraceae & Cyperaceae & DQ917690 & $\begin{array}{l}\text { TUB } \\
014986\end{array}$ & $\mathrm{CE}$ \\
\hline Puccinia silvatica & $\begin{array}{l}\text { Taraxacum officinale } \\
\text { agg. }\end{array}$ & Asteraceae & Cyperaceae & DQ917707 & $\begin{array}{l}\text { TUB } \\
014987\end{array}$ & $\mathrm{CE}$ \\
\hline Puccinia silvatica & Carex brizoides & Asteraceae & Cyperaceae & DQ917708 & $\begin{array}{l}\text { TUB } \\
014988\end{array}$ & $\mathrm{CE}$ \\
\hline Puccinia substriata & Pennisetum glaucum & Solanaceae & Poaceae & DQ917743 & $\begin{array}{l}\text { TUB } \\
014989\end{array}$ & SAf \\
\hline Puccinia tetragoniae & Tetragonia echinata & $?$ & Aizoaceae & DQ917733 & RSA 106 & SAf \\
\hline $\begin{array}{l}\text { Puccina urticata var. } \\
\text { urticae-acutae }\end{array}$ & Carex acuta & Urticaceae & Cyperaceae & DQ917719 & $\begin{array}{l}\text { TUB } \\
014990\end{array}$ & $\mathrm{CE}$ \\
\hline $\begin{array}{l}\text { Puccinia urticata var. } \\
\text { urticae-acutiformis }\end{array}$ & Carex acutiformis & Urticaceae & Cyperaceae & (AF426202) & $\begin{array}{l}\text { TUB } \\
014991\end{array}$ & $\mathrm{CE}$ \\
\hline $\begin{array}{l}\text { Puccinia urticata var. } \\
\text { urticae-biporulae }\end{array}$ & Carex pallescens & Urticaceae & Cyperaceae & DQ917717 & $\begin{array}{l}\text { TUB } \\
014992\end{array}$ & $\mathrm{CE}$ \\
\hline
\end{tabular}




\begin{tabular}{|c|c|c|c|c|c|c|}
\hline Rust species & Host species & I-host & III-host & $\begin{array}{l}\text { GenBank } \\
\text { accession no. }\end{array}$ & Voucher & $\begin{array}{l}\text { Geographical } \\
\text { origin }\end{array}$ \\
\hline $\begin{array}{l}\text { Puccinia urticata var. } \\
\text { urticae-hirtae }\end{array}$ & Carex hirta & Urticaceae & Cyperaceae & DQ917718 & $\begin{array}{l}\text { TUB } \\
014993\end{array}$ & $\mathrm{CE}$ \\
\hline $\begin{array}{l}\text { Puccinia urticata var. } \\
\text { urticae-inflatae }\end{array}$ & Carex rostrata & Urticaceae & Cyperaceae & DQ917720 & $\begin{array}{l}\text { TUB } \\
014994\end{array}$ & $\mathrm{CE}$ \\
\hline Puccinia virgaureae & Solidago virgaurea & - & Asteraceae & DQ917709 & $\begin{array}{l}\text { TUB } \\
014995\end{array}$ & $\mathrm{CE}$ \\
\hline $\begin{array}{l}\text { Puccinia } \\
\text { windhoekensis }\end{array}$ & Coccinia rehmannii & Cucurbitaceae & Cucurbitaceae & DQ917710 & $\mathrm{Na} 152$ & SAf \\
\hline Trachyspora intrusa & $\begin{array}{l}\text { Alchemilla vulgaris } \\
\text { agg. }\end{array}$ & (Rosaceae) & (Rosaceae) & (AF426220) & $\begin{array}{l}\text { TUB } \\
014996\end{array}$ & $\mathrm{CE}$ \\
\hline Uredo guerichiani & $\begin{array}{l}\text { Mesembryanthemum } \\
\text { guerichianum }\end{array}$ & $?$ & Aizoaceae & DQ917722 & RSA 29 & SAf \\
\hline Uredo guerichiani & $\begin{array}{l}\text { Mesembryanthemum } \\
\text { guerichianum }\end{array}$ & $?$ & Aizoaceae & DQ917723 & RSA 153 & SAf \\
\hline Uromyces aloes & Aloe arborescens & - & Asphodelaceae & DQ917740 & WM 3290 & SAf \\
\hline $\begin{array}{l}\text { Uromyces caricis- } \\
\text { sempervirentis }\end{array}$ & Carex sempervirens & Campanulaceae & Cyperaceae & DQ917714 & $\begin{array}{l}\text { GZU 10- } \\
94\end{array}$ & $\mathrm{CE}$ \\
\hline Uromyes cf. ixiae & Lapeirousia sp. & $?$ & Iridaceae & DQ917737 & RSA 211 & SAf \\
\hline Uromyces cf. ixiae & Hesperantha sp. & $?$ & Iridaceae & DQ917736 & RSA 213 & SAf \\
\hline Uromyces dactylidis & Ranunculus acris & Ranunculaceae & Poaceae & DQ917745 & $\begin{array}{l}\text { TUB } \\
014997\end{array}$ & $\mathrm{CE}$ \\
\hline
\end{tabular}




\begin{tabular}{|c|c|c|c|c|c|c|}
\hline Rust species & Host species & I-host & III-host & $\begin{array}{l}\text { GenBank } \\
\text { accession no. }\end{array}$ & Voucher & $\begin{array}{l}\text { Geographical } \\
\text { origin }\end{array}$ \\
\hline Uromyces ficariae & Ranunculus ficaria & - & Ranunculaceae & (AF426204) & $\begin{array}{l}\text { TUB } \\
014998\end{array}$ & $\mathrm{CE}$ \\
\hline Uromyces gageae & Gagea lutea & - & Liliaceae & (AF426208) & $\begin{array}{l}\text { TUB } \\
014999\end{array}$ & $\mathrm{CE}$ \\
\hline Uromyces ixiae & Babiana tubulosa & $?$ & Iridaceae & DQ917738 & RSA 191 & SAf \\
\hline Uromyces ixiae & Babiana cf. sambucina & $?$ & Iridaceae & DQ917739 & RSA 8 & SAf \\
\hline $\begin{array}{l}\text { Uromyces junci (filed } \\
\text { under Tuberculina sp.) }\end{array}$ & Pulicaria dysenterica & Asteraceae & Juncaceae & (AF426203) & $\begin{array}{l}\text { GZU 11- } \\
98\end{array}$ & $\mathrm{CE}$ \\
\hline Uromyces lycoctoni & Aconitum napellus & - & Ranunculaceae & DQ917749 & $\begin{array}{l}\text { TUB } \\
015000\end{array}$ & $\mathrm{CE}$ \\
\hline Uromyces otaviensis & $\begin{array}{l}\text { cf. Ipomoea } \\
\text { verbascoidea }\end{array}$ & Convolvulaceae & Convolvulaceae & DQ917715 & $\mathrm{Na} 305$ & SAf \\
\hline Uromyces pisi & Euphorbia cyparissias & Euphorbiaceae & Fabaceae & (AF426201) & $\begin{array}{l}\text { TUB } \\
015001\end{array}$ & $\mathrm{CE}$ \\
\hline Uromyces poae & Ranunculus ficaria & Ranunculaceae & Poaceae & DQ917744 & $\begin{array}{l}\text { TUB } \\
015002\end{array}$ & $\mathrm{CE}$ \\
\hline Uromyces scutellatus & Euphorbia cyparissias & - & Euphorbiaceae & DQ917713 & $\begin{array}{l}\text { TUB } \\
015003\end{array}$ & $\mathrm{CE}$ \\
\hline Uromyces viciae-fabae & Vicia pannonica & Fabaceae & Fabaceae & (AF426199) & $\begin{array}{l}\text { TUB } \\
015004\end{array}$ & $\mathrm{CE}$ \\
\hline
\end{tabular}


Only the varietal epithets of the rust taxa were used in the phylogenetic trees. These varietal names also represent widely used species synonyms (see Gäumann 1959). GenBank accession numbers of sequences that had been published previously (Maier et al., 2003 and Zambino and Szabo, 1993) are given in parentheses. Herbarium acronyms: CFB (Northern Forestry Centre, Canadian Forest Service, Edmonton, Alberta); FO (F. Oberwinkler, private herbarium); GZU (Karl-Franzens-Universität Graz, Austria); IMI (CABI Bioscience, Egham, UK) M (Botanische Staatssammlung München, Germany); PREM (Plant Protection Research Institute, Pretoria, South Africa); TUB (Eberhards-Karls-Universität Tübingen, Germany); WM (W. Maier, private herbarium) Z + ZT (Combined herbaria of the Universität Zürich and of the ETH Zürich). Na, RSA (collection numbers of collections made by Mennicken in Namibia and South Africa, respectively. These are housed in PREM and Z Z ZT, and PREM and M, respectively. RSA 153 displays double infections with Puccinia aridariae and Uredo guerichiani. Host relationships of the rusts at the family level are given in the columns I-host and IIIhost. "I" refers to aecial host, "III" to telial host. Heteroecious rusts can be identified by two different plant family names in these two columns. Autoecious macrocyclic rusts have the same family name presented twice in these two columns. "_" refers to those species lacking an aecial host and, thus, a short-cyclic rust. "?" refers to an unknown part of the life cycle. The host relationships of the outgroup species are cited in parentheses. Acronyms used for geographical origin: As (Asia), CA (Central America), CE (Central Europe), NA (North America), NE (Northern Europe), SAf (Southern Africa).

\section{DNA-isolation, PCR and DNA-sequencing}

DNA was isolated from the rust spores that were lifted from fruiting structures on infected tissue using insect pins, under a dissecting microscope. Whenever possible these spores were taken from single rust sori to avoid contamination of possible infections by multiple rust species. Spores were crushed between two microscope slides or with the help of a tissue lyser (Retsch Mixer Mill 301, Haan, Germany) by shaking the spores in an Eppendorf tube together with a steel bead $3 \mathrm{~mm}$ diam for $3 \mathrm{~min}$ at $30 \mathrm{~Hz}$. The crushed spores were subsequently suspended in lysis buffer from the Qiagen Plant Mini Kit (Qiagen, Hilden, Germany), following the manufacturer's protocols. PCR and direct 
sequencing of both strands of the $5^{\prime}$ end of the large subunit of the ribosomal gene cluster was performed using the primer pair NL1 and NL4, LR 0R (Moncalvo et al. 1995) and LR 5 or LR 6 (Vilgalys \& Hester 1990). PCR, PCR product purification and cycle sequencing settings were as described previously (Maier et al., 2003 and Ritz et al., 2005). DNA sequence electrophoresis was done on automated DNA sequencers (ABI 373 stretch and ABI PRISM $3100^{\mathrm{TM}}$, Perkin-Elmer, Warrington, UK).

\section{DNA-sequencing and phylogenetic analyses}

Contigs of the double stranded nucleotide sequences were produced, proof-read and edited with the help of Sequencher 4.5 (Gene Codes Corporation, Ann Arbor, MI). From the obtained sequences an alignment was produced with the help of MAFFT 5.66 (Katoh et al. 2005) using the iterative refinement method and the following settings: the Needleman-Wunsch algorithm active, 2 tree rebuilding steps, 1000 iterations and the program's default values for gap opening and gap extension penalties. No further manual manipulation of the alignment was performed. The model of DNA substitution best fitting the data was determined with the help of the Akaike Information Criterion (Akaike 1974) implemented in Modeltest 3.7 (Posada \& Crandall 1998). As a result GTR + I + G (Tavare, 1986 and Rodríguez et al., 1990) was chosen for the following analyses. Phylogenetic estimations based on the obtained alignment were derived with the help of PAUP 4.0b10 (Swofford 2001) using Neighbour Joining (NJ (Saitou \& Nei 1987) and with MrBayes 3.1.1 (Ronquist \& Huelsenbeck 2003), respectively, using Metropolis Coupled Monte Carlo Markov Chains $\left(\mathrm{MC}^{3}\right)$ to approximate the Bayesian posterior probability distribution. Branch support for neighbour joining was determined by 1000 bootstrap replicates. $\mathrm{MC}^{3}$ was run over one million and six million generations, respectively, starting from default (flat) values for the prior settings. Every 100th generation was sampled resulting in 10001 and 60001 trees. Of these the first 2001 and 40001 trees, respectively, were discarded as burn-in and the posterior probability was estimated from the remaining 8000 and 20.000 trees, after the chains had converged to stationarity. Because MrBayes internally runs two independent analyses at once, two independent results for both, the one and six million generations were obtained. All 
phylogenetic trees were rooted with Trachyspora intrusa, Gymnosporangium sabinae and Chrysomyxa empetri.

\section{Results}

\section{Data structure}

The phylogenetic trees obtained are based on the D1/D2 region of the nuclear large subunit of the ribosomal genes. The final alignment contained 550 characters, of which 179 were variable and 100 parsimony informative. The final alignment is deposited at TreeBASE $($ SN 2941; study accession number $=$ S1606, matrix accession umber $=$ M2889). In total 79 specimens representing 70 species were included in these analyses.

\section{Phylogenetic trees}

The tree topologies obtained by Neighbour Joining (Fig 1) and Bayesian phylogenetic inference (Fig 2) are largely congruent for supported clades. The main difference being that in the Bayesian phylogeny, many of the non-supported groups are presented as polytomies. 


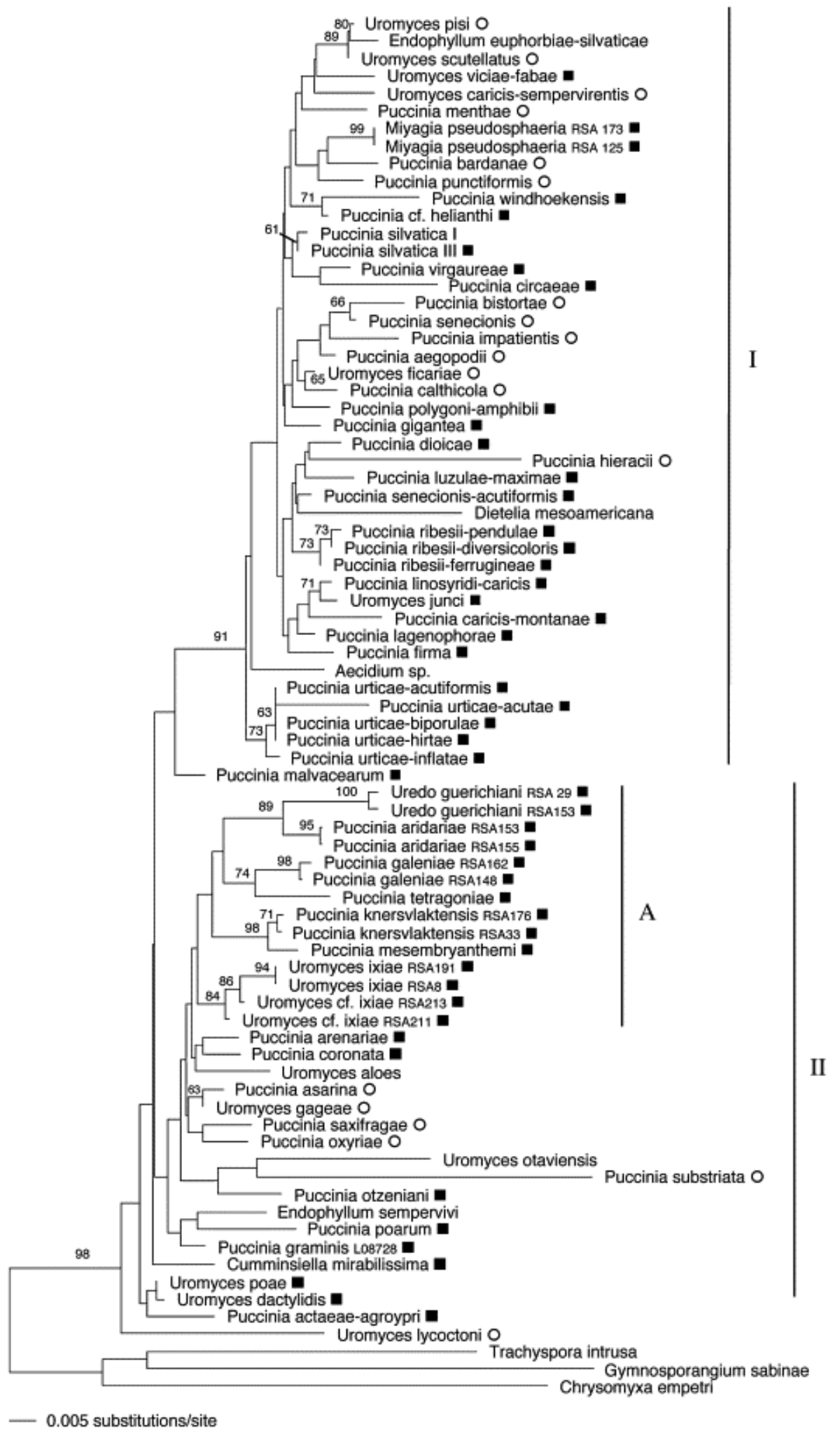

Fig 1. Phylogram obtained by a Neighbour Joining analysis using GTR $+\mathrm{I}+\mathrm{G}$ as DNA substitution model. Bootstrap values above $60 \%$ obtained by 1000 replicates are given 
above branches. Black squares behind species names refer to persistent teliospores (" $\mathrm{Eu}$ Puccinia"); circles refer to dehiscent teliospores ("Bullaria"). "A" stands for the "African clade" discussed in the text. Only the variety epithets of the rust taxa were used in this tree (see the caption of Table 1).

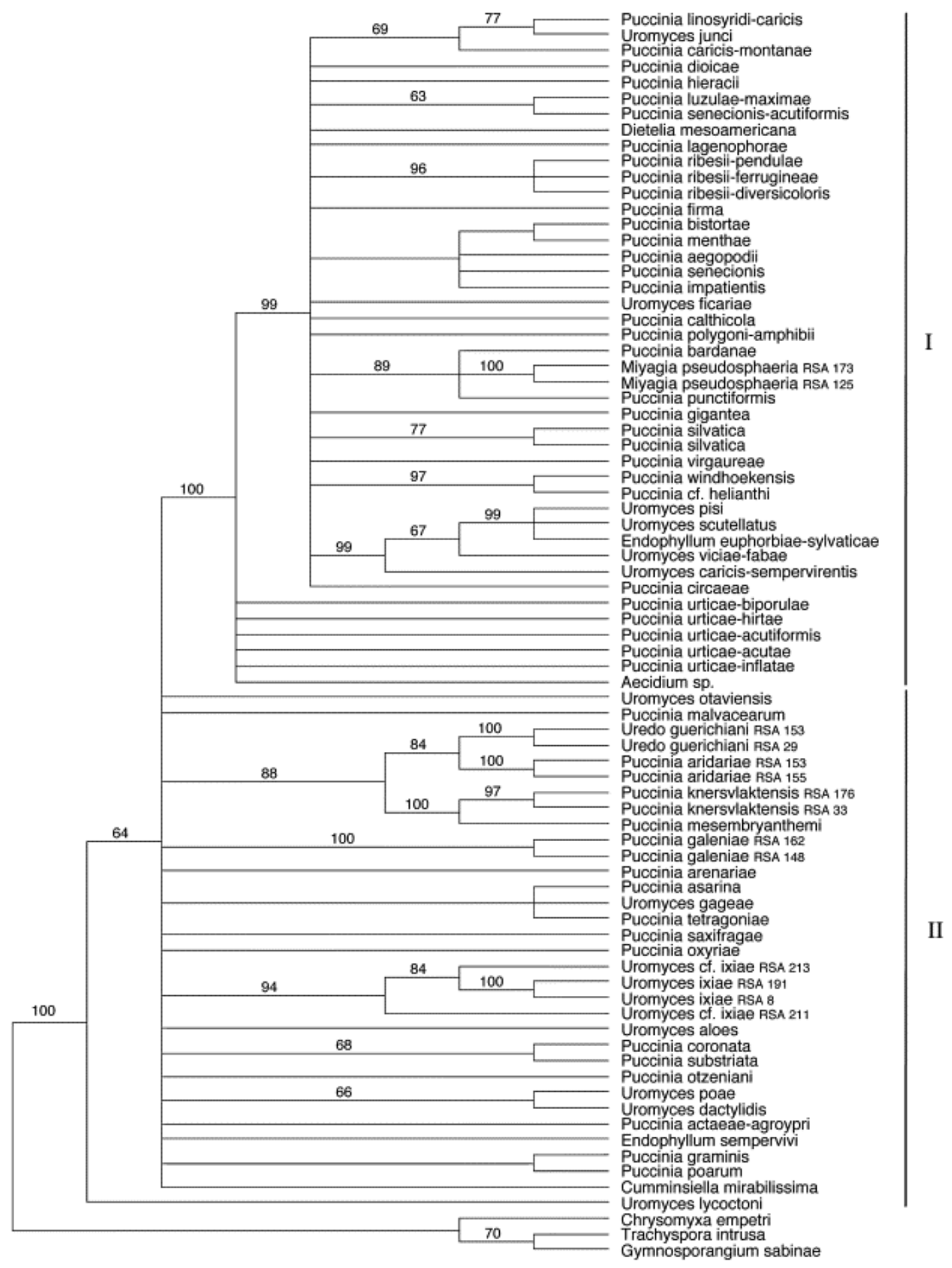


Fig 2. Majority-rule-consensus tree derived from 20000 trees sampled from the stationary phase of a Bayesian Monte Carlo Markov Chain analysis with GTR $+\mathrm{I}+\mathrm{G}$ as nucleotide substitution model. A posteriori probabilities greater than $60 \%$ are given above branches. Two highly supported larger groupings were obvious in both phylograms (Fig 1 and Fig 2). These are the in-group as a whole ( $98 \%$ bootstrap $/ 100 \%$ a posteriori probability), comprising Aecidium, Cumminsiella, Dietelia, Endophyllum, Miyagia, Puccinia, and Uromyces, and the group of species designated as cluster "I" (91\%/100 \%). Only in the Bayesian analyses a large subcluster of cluster I was also highly supported (99 \%). This subcluster was lacking the taxa of Puccinia urticata and the Aecidium sp. sampled. Cluster "II" is then defined as all the species that do not reside in cluster I, but belong to the supported ingroup. Cluster II is however not statistically supported as a monophyletic group itself. Representatives of Aecidium, Endophyllum, Miyagia, Puccinia, and Uromyces resided in cluster I, while cluster II included representatives of Cumminsiella, Endophyllum, Puccinia, Uredo, and Uromyces.

Puccinia, Uromyces, and Endophyllum were clearly polyphyletic, and Puccinia/Uromyces species with Cyperaceae and Juncaceae as telial hosts were found only in Group I. In contrast, species with Poaceae as telial hosts were found only in Group II. Species with dehiscent ("Bullaria") as opposed to non-dehiscent ("EuPuccinia") teliospores, did not correspond to either of the two large clusters accommodating the species included in this study.

\section{Species circumscription as reflected by the phylogenetic data}

In most cases where several collections of the same species were sequenced, the sequences were identical or differed only in one base pair in the gene region being studied (e.g. Miyagia pseudosphaeria, Puccinia aridaria, Uromyces ixiae (RSA 8, RSA 191 in the phylogenetic trees), and Puccinia silvatica. In the case of P. silvatica, sequences were obtained from both the aecial and telial hosts. In a limited number of cases, for example Uromyces cf. ixiae (RSA 211, RSA 213) compared to Uromyces ixiae (RSA 8, RSA 191) differences based on the DNA sequence data were found. It is probable that each of these represent separate taxa and, in this case, undescribed species. 


\section{Discussion}

Results of this study provide clear evidence that Cumminsiella, Dietelia, Endophyllum, Miyagia, Puccinia, Uromyces and, at least parts of the anamorph genera Aecidium and Uredo represent a highly supported monophyletic group of genera. The phylogenetic trees emerging from comparisons of DNA sequence data, however, do not support the generic boundaries of the species that we have included in the study.

In this study, the two largest rust genera, Puccinia and Uromyces, emerged as polyphyletic. While this result was not unexpected, the degree of the polyphyly was surprisingly high. From the phylogenetic analyses, it is clear that the number of cells in the teliospore (one- versus two-celled), which is the basis of the separation between Puccinia and Uromyces, does not have phylogenetic significance. This supports the view of e.g. Anikster \& Wahl (1979: 369) that Puccinia and Uromyces are "only artificially separated from each other". Thus, the transition from either one- to two-celled teliospores, or vice versa or transitions in both directions must have occurred frequently within closely related groups. The taxonomic value of this character is also flawed by species displaying intermediate forms that were included in the present study. Thus, oneand two-celled teliospores are displayed by Puccinia aridariae and Miyagia pseudosphaerica, or one, two, and three-celled by P. galeniae, or two-, three- and fourcelled teliospores by $P$. knersvlaktensis.

Phylogenetic trees showed that Cumminsiella clearly belongs to the Puccinia/Uromyces cluster, which has previously been suggested (Maier et al. 2003). Arthur (1933) recognized that Cumminsiella needed to be segregated from Uropyxis, which accommodated its representatives, because of its strikingly different spermogonial and aecial morphology. It then became clear that based on these characters Cumminsiella was very similar to Puccinia, from which it differs only by having two as opposed to one germ pore per teliospore. It must, however, be noted that certain Puccinia species also display two germ pores per cell (e.g. Puccinia abutili or Puccinia cephalandrae; Mennicken et al. 2005b). All representatives of Cumminsiella are autoecious, most of them macrocyclic and they are naturally restricted to Mahonia and Berberis in the Americas (Baxter, 1957 and McCain and Hennen, 1982). Considering these features collectively, we hypothesize that Cumminsiella is a monophyletic group within 
Puccinia/Uromyces, because the species included in this genus are morphologically and biologically strongly homogenous.

The observation that Miyagia is part of Puccinia/Uromyces supports and enhances the findings of Wingfield et al. (2004). In that study, Miyagia clustered with representatives of Puccinia, Uromyces, and Dietelia with moderate support. More precisely, M. pseudosphaeria formed part of a cluster of autoecious Puccinia species parasitizing Asteraceae in the present study. This corresponds well with the fact that the genus Miyagia includes three species on Asteraceae and it "differs from Puccinia only in the peridiate [formed by palisade-like paraphyses] uredinia and telia" (Cummins \& Hiratsuka 2003). Nevertheless, soral paraphyses represent a variable character within Puccinia species complexes (Savile, 1984 and Anikster et al., 2004). This fact and the phylogenetic placement of Miyagia suggest that soral paraphyses are not phylogenetically useful and it is obvious that the validity of Miyagia should be questioned.

Consistent with observations regarding Miyagia, results of this study suggest that the three species of Corbulopsora, which also display uredinial and telial peridia and are parasitic on Asteraceae, will reside in the Puccinia/Uromyces cluster. Corbulopsora can be interpreted as a one-celled ("Uromyces-type") variant of Miyagia. Cummins (1940) who erected the genus treated it under Miyagia in the first edition of the "Illustrated Genera of Rust Fungi" (Cummins 1959) but the genus was kept separate in the second and third editions of this work (Cummins and Hiratsuka, 1983 and Cummins and Hiratsuka, 2003).

Results of this study show that both the endo-cyclic genera, Endophyllum and Dietelia, are clearly part of Puccinia/Uromyces, and that Endophyllum is polyphyletic. E. sempervivi resides in the phylogenetic Group II, whereas E. euphorbiae-sylvaticae clustered with the heteroecious-macrocyclic $U$. pisi and the microcyclic $U$. scutellatus in Group I. U. pisi alternates between Euphorbia and the genera Lathyrus and Pisum (Fabaceae), while both $U$. scutellatus and E. euphorbiae-sylvaticae are short-cyclic on Euphorbia. This phylogenetic relationship has previously been predicted based on morphological traits and host relationships of these rust fungi by Jørstad (1952) who proposed to transfer E. euphorbiae-sylvaticae to U. euphorbiae-sylvaticae. Also from a phylogenetic point of view, Endophyllum as a whole would need to be included in 
Puccinia/Uromyces, because it merely represents a special (endo) life cycle form of Puccinia/Uromyces as was clearly stated by Tranzschel (1910).

The fact that Dietelia is part of the Puccinia/Uromyces cluster is consistent with previous results based on 18SrDNA sequence data (Wingfield et al. 2004). Despite the fact that Dietelia resides in Pucciniosiraceae as suggested by Cummins \& Hiratsuka (2003) and not in the Pucciniaceae, this is not a surprising result, because Dietelia has the same spermogonial type as Puccinia and Uromyces and it is very similar to Endophyllum. The characters used to distinguish Dietelia from Endophyllum are subtle and include compact versus powdery aecia (aecioid telia according to the ontogentetic concept) and smooth versus ornamented aeciospores (teliospores in the ontogenetic concept) (Buriticá \& Hennen 1980). Using the latter character to distinguish between the two genera was further obscured by the demonstration of verrucose aeciospores in D. codiaei (Boerema et al. 1994). Following the argument already presented for Endophyllum and based on a phylogenetic species concept, Dietelia also would need to be merged with

\section{Puccinia/Uromyces.}

It is no surprise that the sampled representatives of Aecidium and of Uredo belong to the Puccinia/Uromyces cluster. The vast majority of species in these anamorph genera can be expected to belong here.

\section{Sub-generic classification and the host relationships of phylogenetic groupings}

Whether teliospores are borne on fragile versus robust pedicels correlates with phylogenetic groupings was also enquired. The relatively random distribution of this feature when plotted on a phylogenetic tree (Fig 1), however, suggests that it is a variable convergent character that can change in closely related groups. The homoplasious nature of this character had been postulated by Savile, 1954 and Savile, 1971, who gave a plausible ecological-evolutionary explanation for the observation that in closely related species-groups both types of teliospore pedicels can be found. Sub-generic classifications that had been based on this character, like the sub-genera Bullaria and Eu-Puccinia (Arthur 1934) do therefore not contain phylogenetic information.

The two large groups that were found in the present study correlate with the biology of the rust species and thus might represent true sub-generic monophyla. Rusts parasitizing 
Poaceae in their uredinial and telial stages were found in various sub-clusters of species residing in cluster II, but never in cluster I. In contrast, the rusts that are parasitic on Cyperaceae or Juncaceae in their uredinial and telial stages were found only in several sub-clusters of species residing in cluster I of the phylogenetic tree. This pattern is supported by a high bootstrap support for group I, but not for group II, and a comparable pattern has also emerged in another study by van der Merwe et al. (2007) based on other gene regions and a different species sampling. Despite lacking support for the monophyly of group II, this pattern of association could be interpreted in support of the suggestion that Puccinia/Uromyces radiated mainly and independently on Poaceae and Cyperaceae and Juncaceae, respectively, as proposed by Savile (1976). While the Poaceae diversified mainly in dry grassland biomes, the Cyperaceae and Juncaceae radiated in a similar fashion predominantly in wet grassland biomes. Thus, the main-diversifications of Puccinia and Uromyces could have occurred through a mixture of radiation with Poaceae and Cyperaceae/Juncaceae, respectively, and frequent jumps to co-occurring new plant hosts in the respective biomes.

Also several smaller groupings observed in the phylogenetic trees correlate with the families on which these rusts occur, while the grouping of other species indicate that host jumps are likely to have been common within Puccinia/Uromyces, as was postulated before (Savile, 1971, Savile, 1990 and Roy, 2001). One possible example of this intricate relationship between host specificity and host jump, can be found in the group comprising Uromyces pisi, U. scutellatus, E. euphorbiae-silvaticae, U. viciae-fabae and $U$. caricis-sempervirentis within Group I. This group is only highly supported by the MCMC analyses (99\%), nevertheless it is monophyletic in both the MCMC and NJ trees. U. caricis-sempervirentis displays a host shift between Phyteuma (Campanulaceae) and Carex (Cyperaceae), while the other species in this group alternate between Euphorbiaceae and Fabaceae (U. pisi), are macrocyclic-autoecious on Fabaceae (U. viciae-fabae) or are short-cyclic on Euphorbiaceae only (U. scutellatus, Endophyllum euphorbiae-sylvaticae). The current data, however, precluded speculation as to the direction of the presumed host jump in an ancestor of this group. 


\section{Geographical patterns}

Because the majority of species sampled in this study are of European origin, it is pertinent to briefly consider the clustering of species from other geographic origins with them. Within Group II, a cluster exclusively comprising southern African rust species can be found. Although not statistically supported in the NJ tree, a large part of this group is supported by the MCMC phylogram. All species in this group are parasitic on Aizoaceae and thus, it is not only geographic origin but also the host specificity of this group that is reflected by the phylograms. In this context, it is especially important to note that Puccinia otzeniani, which is also parasitic on Aizoaceae in southern Africa, is not part of this group. Thus, rusts on the Aizoaceae have originated from different lineages within group II and are only partly monophyletic. The majority of rusts sampled from southern Africa are part of Group II, which might reflect the fact that large parts of this area are dominated by grasslands and savannas, where Poaceae are especially frequent, and that Cyperaceae, more common in wet lands, are much less frequent. However, there was one southern African representative residing in Group I, P. windhoekensis, suggesting that its origin was from the "Cyperaceae-rust group".

This is the first study based on a considerable taxon sampling using species from a broad range of host families and different geographic origins that has attempted to explore the phylogenetic structure of Puccinia and Uromyces and satellite genera. Intriguing phylogenetic patterns have emerged from the analyses including some that might have been expected and others that are surprising. Nonetheless, the polytomies in the Bayesian consensus tree and many statistically unsupported groupings in general show that various results of this study must be regarded as preliminary. The observed polytomies can be interpreted as reflection of the fact that less than $2 \%$ of the 4500 or so species residing in Puccinia/Uromyces have been sampled. In addition, it is important to consider that the phylogeny is based on sequences of a single gene region, and the value of this gene region especially lies in detecting larger phylogenetic lineages within Puccinia/Uromyces. For these and for practical reasons no name changes have been attempted at this stage. However, the results should serve as a basis for further studies and for large-scale collaborations that will be necessary to address the questions raised here in more detail. 


\section{Addendum}

Additional evidence to support this study is the research presented by van der Merwe et al. (2007). Their study came to our attention only after the experimental part of the present study had been completed. They observe the same major groupings as we report in the present study. However, van der Merwe et al. (2007) used different gene regions and a different subset of species. As the two studies reflect similar results, we have chosen to submit both studies simultaneously in order that they would be published in the same journal issue.

During the review process of the present paper, a combined nuc rDNA SSU/LSU study was published dealing with higher-level relationships of the rust fungi (Aime 2006). This study provides additional support for the view that Aecidium, Cumminsiella, Dietelia, Miyagia, Puccinia and Uromyces have a common origin. Pucciniosira and Sphenospora also formed part of that clade, and Puccinia and Uromyces were again shown to be polyphyletic.

\section{References}

Aime, 2006 M.C. Aime, Toward resolving family-level relationships in rust fungi (Uredinales), Mycoscience 47 (2006), pp. 112-122.

Akaike, 1974 H. Akaike, A new look at the statistical model identification, IEEE Transactions on Automatic Control AC-19 (1974), pp. 716-723.

Anikster and Wahl, 1979 Y.T. Anikster and I. Wahl, Coevolution of the rust fungi on Gramineae and Liliaceae and their hosts, Annual Review of Phytopathology 17 (1979), pp. 367-403.

Anikster et al., 2004 Y. Anikster, L.J. Szabo, T. Eilam, J. Manisterski, S.T. Koike and W.R. Bushnell, Morphology, life cycle biology, and DNA sequence analysis of rust fungi on garlic and chives from California, Phytopathology 94 (2004), pp. 569-577.

Arthur, 1906 J.C. Arthur, Eine auf die Struktur und Entwicklungsgeschichte begründete Klassifikation der Uredineen, Wissenschaftlich Ergebnisse des Internationalen Botanischen Kongresses, Wien 1905 (1906), pp. 331-348.

Arthur, 1933 J.C. Arthur, New genera and species of Uredinales, Bulletin of the Torrey Botanical Club 60 (1933), pp. 475-476. 
Arthur, 1934 J.C. Arthur, Manual of the rusts in United States and Canada, Purdue Research Foundation, Lafayette, Indiana (1934).

Baxter, 1957 J.W. Baxter, The genus Cumminsiella, Mycologia 49 (1957), pp. 864-873.

Boerema et al., 1994 G.H. Boerema, R.T.A. Cook, J.S.W. Dickens, A. Pisi, M.G. Bellardi and J.E.M. Mordue, Codiaeum rust, Plant Pathology 43 (1994), pp. 1072-1079.

Buriticá and Hennen, 1980 P. Buriticá and J.F. Hennen, Pucciniosireae (Uredinales, Pucciniaceae), The New York Botanical Garden, Bronx, New York (1980).

Cummins, 1940 G.B. Cummins, Uredinales of New Guinea, Mycologia 32 (1940), pp. 359-375.

Cummins, 1959 G.B. Cummins, Illustrated Genera of Rust Fungi, Burgess Publishing, Minneapolis, MN (1959).

Cummins and Hiratsuka, 1983 G.B. Cummins and Y. Hiratsuka, Illustrated Genera of Rust Fungi, The American Phytopathological Society, St Paul, MN (1983).

Cummins and Hiratsuka, 2003 G.B. Cummins and Y. Hiratsuka, Illustrated Genera of Rust Fungi (3rd ed.), The American Phytopathological Society, St Paul, MN (2003).

Dietel, 1899 P. Dietel, Waren die Rostpilze in früheren Zeiten plurivor? (Schluss.), Botanisches Centralblatt 74 (1899), pp. 113-117.

Dietel, 1922a P. Dietel, Kleine Beiträge zur Systematik der Uredineen. II, Annales Mycologici 20 (1922), pp. 174-177.

Dietel, 1922b P. Dietel, Kleine Beiträge zur Systematik der Uredineen, Annales Mycologici 20 (1922), pp. 29-33.

Doidge, 1950 E.M. Doidge, The South African fungi and lichens to the end of 1945, Bothalia 5 (1950), pp. 1-1094.

Fischer, 1904 E. Fischer, Die Uredineen der Schweiz, K.J. Wyss, Bern (1904).

Gäumann, 1926 E. Gäumann, Vergleichende Morphologie der Pilze, G. Fischer Verlag, Jena (1926).

Gäumann, 1959 E. Gäumann, Die Rostpilze Mitteleuropas, Buechler, Bern (1959).

Guyot, 1938 A.L. Guyot, Les Urédinées, Vol. I, Genre Uromyces, Paul Lechevalier, Paris (1938).

Hennen et al., 2005 J.F. Hennen, M.B. Figueiredo, A.A. de Carvalho Jr. and P.G. Hennen, Catalogue of the species of plant rust fungi (Uredinales) of Brazil (2005). 
Hennings, 1897 P. Hennings, Beiträge zur Pilzflora Südamerikas. II, Hedwigia 36 (1897), pp. 190-248.

Jørstad, 1952 I. Jørstad, Parasitic fungi, chiefly Uredineae, from Tirich Mir in the State of Chitral, N. Pakistan, Nytt Magasin for Botanikk 1 (1952), pp. 71-87.

Katoh et al., 2005 K. Katoh, K. Kuma, H. Toh and T. Miyata, MAFFT version 5: improvement in accuracy of multiple sequence alignment, Nucleic Acids Research 33 (2005), pp. 511-518.

Klebahn, 1914 H. Klebahn, Uredineae, Kryptogamenflora der Mark Brandenburg Band Va, Gebrüder Borntraeger, Leipzig (1914) 69-904.

Leppik, 1959 E.E. Leppik, Some viewpoints on the phylogeny of rust fungi. III. Origin of grass rusts, Mycologia 51 (1959), pp. 512-528.

Léveillé, 1826 J.H. Léveillé, Observations sur deux champignons de la famille des Urédinées, Mémoirs de la Société Linnéenne Paris 4 (1826), pp. 202-212.

Maier et al., 2003 W. Maier, D. Begerow, M. Weiß and F. Oberwinkler, Molecular phylogeny of the rust fungi: an approach using nuclear large subunit ribosomal DNA sequences, Canadian Journal of Botany 81 (2003), pp. 12-23.

McAlpine, 1906 D. McAlpine, The Rusts of Australia, Robt. S. Brain, Government Printer, Melbourne (1906).

McCain and Hennen, 1982 J.W. McCain and J.F. Hennen, Is the taxonomy of Berberis and Mahonia (Berberidaceae) supported by their rust pathogens Cumminsiella santa sp. nov. and other Cumminsiella species?, Systematic Botany 7 (1982), pp. 48-59.

Mennicken et al., 2005a M. Mennicken, W. Maier, P.W. Crous and F. Oberwinkler, A contribution to the rust flora (Uredinales) on Aizoaceae in southern Africa, Mycological Progress 4 (2005), pp. 215-224.

Mennicken et al., 2005b M. Mennicken, W. Maier and F. Oberwinkler, A contribution to the rust flora (Uredinales) of southern Africa, with an emphasis on Namibia, Mycological Progress 4 (2005), pp. 55-75.

Mennicken et al., 2005c M. Mennicken, W. Maier and F. Oberwinkler, A contribution to the rust flora (Uredinales) on Zygophylloideae (Zygophyllaceae) in Africa, Mycotaxon 91 (2005), pp. 39-48. 90 
Mennicken and Oberwinkler, 2004 M. Mennicken and F. Oberwinkler, A contribution to the rust flora (Uredinales) of southern Africa, with an emphasis on South Africa, Mycotaxon 90 (2004), pp. 1-28.

Miyabe, 1913 K. Miyabe, Miyagia, Annales Mycologici 11 (1913), pp. 93-118.

Moncalvo et al., 1995 J.-M. Moncalvo, H.-H. Wang and R.-S. Hseu, Phylogenetic relationships in Ganoderma inferred from the internal transcribed spacers and 25S ribosomal DNA sequences, Mycologia 87 (1995), pp. 223-238.

Posada and Crandall, 1998 D. Posada and K.A. Crandall, MODELTEST: testing the model of DNA substitution, Bioinformatics 14 (1998), pp. 817-818.

Ritz et al., 2005 C.M. Ritz, W.F.A. Maier, F. Oberwinkler and V. Wissemann, Different evolutionary histories of two Phragmidium species infecting the same dog rose hosts, Mycological Research 109 (2005), pp. 603-609.

Rodríguez et al., 1990 F. Rodríguez, J.L. Oliver, A. Marín and J.R. Medina, The general stochastic model of nucleotide substitution, Journal of Theoretical Biology 142 (1990), pp. 485-501.

Ronquist and Huelsenbeck, 2003 F. Ronquist and J.P. Huelsenbeck, MrBayes 3:

Bayesian phylogenetic inference under mixed models, Bioinformatics 19 (2003), pp. 1572-1574.

Roy, 2001 B.A. Roy, Patterns of association between crucifers and their flower-mimic pathogens: host jumps are more common than coevolution or cospeciation, Evolution 55 (2001), pp. 41-53.

Saitou and Nei, 1987 N. Saitou and M. Nei, The neighbor-joining method: A new method for reconstructing phylogenetic trees, Molecular Biology and Evolution 4 (1987), pp. 406-425.

Savile, 1954 D.B.O. Savile, Cellular mechanics, taxonomy and evolution in the Uredinales and Ustilaginales, Mycologia 46 (1954), pp. 736-761.

Savile, 1971 D.B.O. Savile, Coevolution of the rust fungi and their hosts, The Quarterly Review of Biology 46 (1971), pp. 211-218.

Savile, 1976 D.B.O. Savile, Evolution of the rust fungi (Uredinales) as reflected by their ecological problems, Evolutionary Biology 9 (1976), pp. 137-207. 
Savile, 1984 D.B.O. Savile, Taxonomy of the cereal rust fungi, Taxonomy of the cereal rust fungi, Academic Press, Orlando, FL (1984), pp. 79-112.

Savile, 1990 D.B.O. Savile, Coevolution of Uredinales and Ustilaginales with vascular plants, Reports of the Tottori Mycological Institute 28 (1990), pp. 15-24.

Swofford, 2001 D.L. Swofford, PAUP*. Phylogenetic Analysis Using Parsimony (*and other methods), Version 4b10, Sinauer Associates, Sunderland, MA (2001).

Sydow, 1921 H. Sydow, Die Verwertung der Verwandtschaftsverhältnisse und des gegenwärtigen Entwicklungsganges zur Umgrenzung der Gattungen bei den Uredineen, Annales Mycologici 19 (1921), pp. 161-175.

Sydow and Sydow, 1904 P. Sydow and H. Sydow, Monographia Uredinearum. Volumen I: Genus Puccinia, Gebrüder Borntraeger, Leipzig (1904).

Sydow and Sydow, 1910 P. Sydow and H. Sydow, Monographia Uredinearum. Volumen II: Genus Uromyces, Gebrüder Borntraeger, Leipzig (1910).

Tavare, 1986 S. Tavare, Some probabilistic and statisical problems on the analysis of DNA sequences, Lectures on Mathematics in the Life Sciences 17 (1986), pp. 57-86. Tranzschel, 1904 W. Tranzschel, Über die Möglichkeit, die Biologie wirtswechselnder Rostpilze auf Grund morphologischer Merkmale vorauszusehen, Arbeiten der Kaiserlichen St. Petersburger Naturforschenden Gesellschaft 35 (1904), pp. 311-313. Tranzschel, 1910 W. Tranzschel, Die auf der Gattung Euphorbia auftretenden autöcischen Uromyces-Arten, Annales Mycologici 8 (1910), pp. 3-35.

Tranzschel, 1939 W. Tranzschel, Conspectus of the Rust Fungi of the USSR [In Russian.] (1939) Leningrad.

Tulasne, 1854 L.R. Tulasne, Second mémoire sur les Urédinées et les Ustilaginées, Annales des Sciences Naturelles Botanique Série 4 (1854), pp. 77-196. van der Merwe et al., 2007 M. van der Merwe, L. Ericson, J. Walker, P.H. Thrall and J.J. Burdon, Evolutionary relationships among species of Puccinia and Uromyces (Pucciniaceae Uredinales) inferred from protein coding gene phylogenies, Mycological Research 111 (2007), pp. 163-175.

Vilgalys and Hester, 1990 R. Vilgalys and M. Hester, Rapid genetic identification and mapping of enzymatically amplified ribosomal DNA from several Cryptococcus species, Journal of Bacteriology 172 (1990), pp. 4238-4246. 
Wingfield et al., 2004 B.D. Wingfield, L. Ericson, T. Szaro and J.J. Burdon, Phylogenetic patterns in the Uredinales, Australasian Plant Pathology 33 (2004), pp. 327-335.

Wood and Crous, 2005 A.R. Wood and P.W. Crous, Morphological and molecular characterization of Endophyllum species on perennial asteraceous plants in South Africa, Mycological Research 109 (2005), pp. 387-400.

Zambino and Szabo, 1993 P.J. Zambino and L.J. Szabo, Phylogenetic relationships of selected cereal and grass rusts based on rDNA sequence analysis, Mycologia 85 (1993), pp. $401-414$.

Appendix. Supplementary material $(26 \mathrm{~K})$

f.xls (3) ralp

Microsoft Excel file 1. (Afglaai) 